DOI https://doi.org/10.30525/978-9934-26-173-2-29

\title{
ФІЛОСОФІЯ ОСВІТИ В УМОВАХ ПАНДЕМІЧНОЇ НЕСТАБІЛЬНОСТІ
}

\author{
Лисенко С. О. \\ дочент кафедри сочіально-гуманітарних наук \\ Придніпровська державна академія фізичної культури і спорту \\ м. Дніпро, Украӥна
}

У більшій частині сучасної філософії освіти діагнози соціальнополітичних патологій лежать в основі бачення більш бажаного, демократичного майбутнього [1]. Реальність сучасного світу, в умовах пандемічної нестабільності, призводить до диференціації філософського знання. Величезна кількість підходів, концепцій, теорій, вимагає потребу окремо осмислити феномени навколишнього світу, а також стимулює появу різних самостійних галузей у філософії: філософія освіти, філософія техніки, філософія науки, філософія права тощо. Філософія освіти працює з першоосновами, фундаментальними принципами та парадигмами, на яких вже має будуватися система освіти та методичні проекти педагогіки щодо реалізації цих основних засад.

Сучасна освіта як і процес, і система, і цінність, повинна мати під собою опору - парадигмальні положення філософії освіти. Філософія освіти акцентує увагу на загальних біологічних, соціальних, культурологічних й інших факторах та закономірностях впливу на процес формування людини. Специфіка сучасної культури змінює буття людини, вносить корективи до специфіки освіти. Швидкі темпи життя примушують адаптуватися та підлаштовуватися до них, тим самим змінювати звичну дійсність. Плюралістичність підходів, і водночас спроби по-філософськи осмислити, узагальнити сучасну освіту в умовах пандемічної нестабільності, трансформує філософію освіти [2].

Деякі $з$ найновіших освітньо-філософських робіт та дослідницьких проектів з сучасної освіти характеризують цей вік як «часи пандемії» або «епоху глобальних криз», пропонуючи «ліки» від іiї патологій. Тобто в сучасній філософії освіти діагностика часу лежить в основі бачення більш бажаного майбутнього, такого як демократичне, деколоніальне, всеохоплююче, екологічне, постцифрове тощо [1].

Філософія надала сучасній освіті системності та структурності, оскільки без філософії освіта не здатна до трансгресії. Оскільки як філософія, так і освіта знаходяться у діалектичній взаємозалежності. Розглядаючи поняття «класична парадигма освіти», яке було 
сформульовано наприкінці XVIII сторіччя на основі педагогічних та філософських ідей Я. Коменського, Й. Песталоцці, Ж. Руссо, Дж. Дьюї та ін. Модель тогочасної освіти базувалася на основі репродуктивного знання. Тогочасна система освіти $€$ досить консервативною, лінійною, яка нездатна до швидких змін у суспільстві.

I. Предборська зазначає, що людина в епоху глобалізованого суспільства «перетворюється в клієнта, який підпорядкований стандартам «суспільства споживання» та позбавляється можливості вибору і формування освітньо-культурного середовища у відповідності до своїх ціннісних стандартів» [3, с. 8]. Тому філософія освіти в умовах пандемічної нестабільності вимагає внести зміни в світоглядні орієнтири, в процес формування критичного мислення, а також впровадження ідей постнекласичної науки та синергетики в освіту, зближення природничих і гуманітарних наук, посилення ролі філософії в осмисленні соціальної реальності в умовах пандемічної нестабільності, побудови освітнього процесу на ідеях нелінійності, що і призводить до зміни поглядів на парадигму сучасної освіти [4].

3-за даних умов актуальним завданням являється формування новітньої парадигми підготовки особистості до життя, яка б забезпечила не тільки адаптивне ставлення до дійсності, але й її розвиток у відпо-

відності до преферентних у суспільстві цінностей, духовних імперативів та ідеалів. Пандемія COVID-19 сприяла продукуванню нової філософії освіти, яка супроводжує людину впродовж усього життя та значно розширює спектр світоглядних позицій, які сприяють розвитку критичного мислення, які є необхідними для набуття фахових компетентностей та успішного оволодіння професійною діяльністю [5].

Пандемія коронавірусу спричинила зміни у процесі навчання та вплинула на взаємодію між педагогами та здобувачами освіти, як наслідок, навчальні заклади здійснюють освітній процес в мережі Інтернеті (Sobaih, Hasanein, Abu Elnasr, 2020) [6]. Нововведення в традиційному навчанні спричинили зміни парадигми у сприйнятті здобувачами освіти дистанційного навчання, i їx сприйняття може відрізнятися від того, яке було виявлено в дослідженнях, що передували пандемії COVID-19. Оскільки попередні дослідження показують, що дистанційне навчання пропонує багато переваг для здобувачів освіти, бо цей тип навчання є більш гнучким та передбачає орієнтованість на особистість (Dhawan, 2020) [7], а також може покращити взаємодію зі здобувачами освіти шляхом надання інструментів, таких як електронна пошта, форуми, чати, відеоконференції тощо (Marinoni et al. 2020; Anwar, Adnan, 2020) [8].

Тому, філософія завжди намагалася зрозуміти існуючу освітню систему та сформулювати перспективи освітньої системи майбутнього, 
яка сприяє розумінню цілей освіти та виховання. Нерозривність філософії та освіти може бути оцінена на основі їх спільних питань та проблем. Вони розглядають проблеми мети виховання; проблеми формування світогляду; взаємозв’язок колективу та особистості; гносеологічні проблеми, пов'язані 3 розробкою теорії пізнання та учнівського пізнання як однією з форм пізнання людиною навколишньої його дійсності. Варто також зазначити, що освіта також тісно пов’язана 3 відносно незалежними філософськими областями, такими як етика та естетика, які допомагають вирішити педагогічні завдання етичного, морального виховання, формування наукового бачення світу. Як у будь-якій галузі, у філософії сучасної освіти в умовах пандемічної нестабільності наявні наступні актуальні проблеми (див. рис. 1) [9; 10].

\begin{tabular}{|c|} 
Проблеми у філософії сучасної освіти \\
\hline $\begin{array}{l}\text { 1. Лінійність освіти. } \\
\text { В даний час в освіті замість можливості використання освіти для актуалізації } \\
\text { потенціалу та самореалізації особистості запроваджується принцип відповідності } \\
\text { освітньму стандарту. Саме тому в процесі освіти так багато уваги приділяють } \\
\text { оцінкам, накопиченим балам, сертифікатам, рейтингам освітніх організацій. } \\
\text { Важливим єлише результат, завдяки якому здобувач освіти або вступить на навчання, } \\
\text { або залишиться на рік або піде вчитися платно. У результаті, здобувачу освіти нічого } \\
\text { не залишається як «підганяти» свої можливості в рамках формальних вимог. }\end{array}$ \\
\hline \hline $\begin{array}{l}\text { 2. Регрес мислення та інтелекту під впливом комп'ютерних технологій та } \\
\text { Інтернету. } \\
\text { Практично будь-яку навчальну інформацію зараз можна знайти в мережі Інтернет. } \\
\text { Людина максимально спростила собі життя, а якщо так продовжувати жити, то люди } \\
\text { скоро взагалі перестануть розвиватися інтелектуально, тому потрібно займатися } \\
\text { самоосвітою та професійно розвиватися впродовж життя. }\end{array}$ \\
\hline $\begin{array}{l}\text { 3. Проблема досягнення ідеалу особистості. } \\
\text { У рамках філософії освіти створилися рамки високоморальної людини з бажанням } \\
\text { здобувати нові знання. Інакше кажучи, педагогами створився «ідеал» здобувача } \\
\text { освіти, під який вони намагаються підвести кожного свого вихованця. Але при цьому } \\
\text { зовсім не враховуються розумові здібності та особливості особи. }\end{array}$ \\
\hline
\end{tabular}

\section{Рис. 1. Проблеми у філософії сучасної освіти}

Примітка: складено на основі джерела: [2]

Таким чином, з-за сучасних умов пандемічної нестабільності, актуальність філософії освіти зростає, оскільки освіта визначається, як стратегічний ресурс, цінність, тому i зростає актуальність іiі філософського дослідження. Отже, філософія освіти в умовах пандемічної нестабільності визначається як важлива складова філософської 
системи і покликана систематизувати знання про освітній процес, та визначати стратегічний вектор його розвитку на найближчий час.

\section{Лiтература:}

1. Papastephanou M. Philosophy of Education in Times of Crises and Pandemics. Education Sciences. 2021, vol. 11(11), pp. 687. URL: https:// doi.org/10.3390/educsci11110687 (дата звернення: 25.11.2021).

2. Kozlova T. A., Polyakova J. O., Leontyeva D. A. Formation of philosophical anthropology as a subject in higher education. Karelian scientific journal, 2020, vol. 9. URL: 10.26140/knz4-2020-0902-0007 (дата звернення: 25.11.2021).

3. Філософські абриси сучасної освіти : [монографія] / За заг. ред. I. М. Предборської. Суми: Університетська книга, 2015. 226 с.

4. Щербатюк А. Д., Березінець I. В. Філософське підгрунтя сучасної освіти. 2016. URL: file:///C:/Users/111/Downloads/-.pdf (дата звернення: 25.11.2021).

5. Костючков С. К. Філософські засади розвитку дистанційної освіти в умовах сучасного інформаційного простору. Дистанційне навчання студентів: теорія $i$ практика [Електронний збірник]: науково-методичні праці Херсонського державного університету / відп. ред. С.А. Омельчук. Херсон : ХДУ, 2020. С. 42-51.

6. Sobaih A.E.E., Hasanein A.M., Abu Elnasr A.E. Responses to COVID-19 in Higher Education: Social Media Usage for Sustaining Formal Academic Communication in Developing Countries. Sustainability, 2020, vol. 12, pp. 6520 .

7. Dhawan S. Online Learning: A Panacea in the Time of COVID-19 Crisis. J. Educ. Technol. Syst., 2020, vol. 49, pp. 5-22.

8. Anwar K., Adnan M. Online learning amid the COVID-19 pandemic: Students perspectives. J. Pedagog. Res., 2020, vol. 1, pp. 45-51.

9. Косенко Т.С., Наливайко Н.В., Лигостаев А.Г., Яковлева И.Г. Соотношение философии и философии образования как методологическая основа управления развитием системы отечественного образования в современных условиях. Философия образования, 2018. № 3 C.196.

10. Наливайко Н.В., Косенко Т.С., Яковлева И.В. Современная личность в информационном пространстве: возможности образования. Философия образования. 2017. № 4. с. 145.

11. Чиркова В.М. Развитие научной деятельности в учреждениях высшего профессионального образования. Карельский научный журнал, 2018. Том 7. № 4 (25). С. 49-52. 